\title{
Implementasi Metode Case Based Reasoning Untuk Mendeteksi Kerusakan Televisi
}

\author{
Sursih Wulandari*, Marnis Nasution, Mustafa Haris Munandar \\ Manajemen Informatika, Universitas Labuhan Batu, Rantauprapat, Indonesia \\ Email: ${ }^{1}$ wsurasih@gmail.com \\ Email Penulis Korespondensi: wsurasih@gmail.com
}

\begin{abstract}
Abstrak- Proses kerusakan televisi memang sebaiknya dolakukan oleh seorang pakar yang merupakan seorang pakar televisi itu sendiri,namun dikarenakan televisi merupakan alat yang sudah tidak lazim lagi orang mengenalnya maka masyarakat juga sudah banyak yang memiliki televisi dirumah mereka masing-masing. Untuk perbaikan televisi tersebutpun memerlukan biaya yang cukup mahal maka sebagian masyarakat yang memiliki televisi bisa melakukan perawatan televisi dirumah. Minimnya pengetahuan yang dimiliki oleh masyarakat dapat menyebabkan penanganan yang salah terhadap pemeliharaan/perawatan televisi dan hal ini berdampak fatal. Keberadaan sistem ini semoga dapat membantu masyarakat dalam mendiagnosa kerusakan televisi mereka. Dalam hal ini mereka tidak perlu repot-repot untuk memanggil reparasi atau membawaketempat reparasi televisi. Disini penulis memberikan solusu-solusinya untuk menyelesaikan masalah-masalah yang timbul pada televisi yang sering muncul. Dalam penelitian ini membahas tentang memberikan cara perawatan-perwawan Televisi . Adapun tujuan penelitian adalah menganalisis suatu program sistem pakar berbasis dekstop yang berisi pengetahuan dari seorang pakar/dokter yang diyakini kebenarannya yang memiliki kemampuan untuk dapat mendiagnosa penyakit dari gejala-gejala kerusakan yang yang mengalami kerusakan televisi secara cepat dan tepat. Tahapan penelitian yang dilakukan dalam penelitian ini diantaranaya studi literature, pengumpulan data, peracangan system, pembuatan system, pengujian systemPenalaran berbasis kasus/Case Based Reasoning merupakan metode yang dipergunakan untuk membangun sebuah sistem berbasis pengetahuan. Sumber pengetahan sistem diproleh dngan mengumpulkan penanganan kasus-kasus oleh seorang ahli/pakar. Oleh karena itu banyaknya masalah-masalah dalam kerusakan televisi itu biasanya karena adanya kelalaian pemilik televisi itu sendiri. Lagkah pertama dalam menyelesaikan masalah adalah dengan cara mengidentifikasi terlebih dahulu ruang lingkup permasalahan yang akan diselesaikan, hal ini berlaku juga untuk setiap pemrograman Artifical Intellegence (AI). Hasil penelitian yang didapatkan dalam penelitian untuk diagnosa penyakit konjungtivitis adalah nilai dari kasus lama dan kasus baru didapatkan nilai bobot yang tinggi yaitu 1 dari kasus ketiga.
\end{abstract}

Kata Kunci: Diagnosa; Case Based Reasoning; Kerusakan; Sistem Pakar; Televisi.

Abstract-The process of deteriorating television should indeed be done by an expert who is a television expert himself, but because television is a tool that is no longer common for people to know him, many people also have television in their respective homes. Even for television repairs, it is quite expensive, so some people who have televisions can do television maintenance at home. The lack of knowledge possessed by the community can lead to wrong handling of television maintenance / maintenance and this has a fatal impact. Hopefully the existence of this system can help the community in diagnosing the damage to their televisions. In that case they need not bother to call for repairmen or bring in a television repair shop. Here the authors provide solutions to solve the problems that often arise on television. In this study, it discusses how to care for television officers. The research objective is to analyze a desktop-based expert system program that contains the knowledge of an expert / doctor whose truth is believed to have the ability to be able to diagnose the disease from the symptoms of damage that has been damaged by television damage quickly and precisely. The stages of research carried out in this study include literature study, data collection, system design, system creation, system testing. Case Based Reasoning is a method used to build a knowledge-based system. The source of system knowledge is obtained by collecting the handling of cases by an expert / expert. Therefore, many problems in television damage are usually due to the negligence of the television owner himself. The first step in solving a problem is by first identifying the scope of the problem to be resolved, this also applies to any Artificial Intelligence (AI) programming. The results obtained in the study for the diagnosis of conjunctivitis were the value of old cases and new cases which obtained a high weight value, namely 1 from the third case.

Keywords: Diagnosis; Case Based Reasoning; Damage; Expert System; Television

\section{PENDAHULUAN}

Sebuah sistem memilik dua elemen utama yaitu basis pengetahuan knowledge based dan kemampuan penalaran / reasoning. Menurut [1] basis pengetahuan merupakan elemen utama sistem karena komponen ini berisi sumber kecerdasan sistem. Banyak metode yang membangun sebuah basis pengetahuan diantaranya melalui interaksi langsung pembangun pengetahuan ahli / pakar melalui wawancara atau observasi atau melalui catatan penanganan kasus yang pernah dilakukan oleh seorang ahli. Akusisi pengetahuan melalui catatan penanganan kasus yang pernah dilakukan oleh ahli memiliki banyak keuntungan diantara pengembangan sistem tidak perlu berhubungan langsung dengan pakar dan proses akusisi dapat lebih singkat, sehingga memperpendek waktu pengembangan sistem. Metode yang digunakan untuk membangun sebuah sistem berbasis pengetahuan yang yang pengetahuannya bersumber dari catatan kasus-kasus lampau dikenal dengan Case Based Reasoning (CBR)[2]

Pada penelitian[3] yang akan dilakukan menetapkan metode case based reasoning (CBR) untuk membangun sebuah sistem yang memiliki kemampuan untuk mendiagnosa kerusakan pada telivisi perbedaan penelitian yang dilakukan dengan penelitian yang diangkat adalah jumlah gejala dari penelitian sebelumnya dengan jumlah gejala yang dilakukan jauh lebih banyak sehingga keakuratan tingkat kecocokan jauh lebih baik. 
Proses kerusakan televisi memang sebaiknya dilakukan oleh seorang pakar yang merupakan seseorang pakar televisi itu sendri, namun dikarenakan televisi merupakan alat yang sudah tidak lajim lagi orang mengenalnya maka masyarakat juga sudah banyak yang memiliki televisi dirumah mereka masing-masing. Untuk perbaikan televisi tersebut pun memerlukan biaya yang cukup mahal maka sebagian masyarakat yang memiliki televisi bisa melakukan perawatan televisinya sendiri dirumah. Minimnya pengetahuan yang dimiliki oleh masyarakat dapat menyebabkan penanganan yang salah terhadap perawatan televisi mereka dan hal ini berdampak fatal. Keberadaan sistem ini semoga dapat membantu masyarakat dalam mendiagnosa kerusakan televisi mereka. Dalam hal ini masyarakat tidak perlu repot-repot untuk memanggil teknisi untuk melakukan reparasi atau membawa ketempat reparasi televisi. Disini penulis memberikan solusi-solusinya untuk menyelesaikan masalah-masalah yang timbul pada televisi yang sering muncul. penelitian ini penulis juga memberikan cara perawatan-perawatan televisi, agar televisi yang digunakan tahan lama, dan tidak mengurangi efek warna pada televisi.

Dalam penelitian [4][5] sistem pakar adalah bagian dari kecerdasan buatan yang mengandung pengetahuan dan pengalaman yang dimasukkan oleh banyak pakar kedalam suatu area tertentu. Sehingga setiap orang yang menggunakannya untuk memecahkan berbagai masalah yang bersifat spesifik. Oleh karena itu banyaknya masalah-masalah dalam kerusakan televisi itu biasanya di karena solderan timah yang kurang baik sehingga kakikaki komponen tidak tersambung pada sempurna ke gejala dan penyebab kerusakan TV bermacam-macam,gejala yang timbul dapat berupa mati total, tidak ada suara dan hasil ga,mbar yang jelek. Menurut [6] langkah pertama dalam menyelesaikan masalah adalah dengan cara mengidentifikasi terlebih dahulu ruang lingkup permasalahan tersebut atau domain untuk permasalahan yang akan diselesaikan, hal ini berlaku juga untuk setiap pemerograman Artifical Intellegence (AI).

Metode CBR merupakan metode untuk menyelesaikan masalah dengan mengingat kejadian-kejadian yang sama/sejenis (similar) yang pernah terjadi di masa lalu kemudian menggunakan pengetahuan/informasi tersebut untuk menyelesaikan masalah yang baru, atau dengan kata lain menyelesaikan masalah dengan menghadapi solusisolusi yang pernah digunakan di masa lalu.

\section{METODOLOGI PENELITIAN}

\subsection{Tahapan Penelitian}

Dalam menyelesaikan penelitian ini melakukan penelitian dengan metode meneliti berdasarkan fakta-fakta, objek dan juga permasalahan dan kebutuhan yang sudah dikumpulkan selanjutnya dianalisa dengan tujuan menghasilkan suatu kesimpulan dari deskripsi yang secara sistematis. Tahapan penelitian dapat dilihat pada gambar 1 .

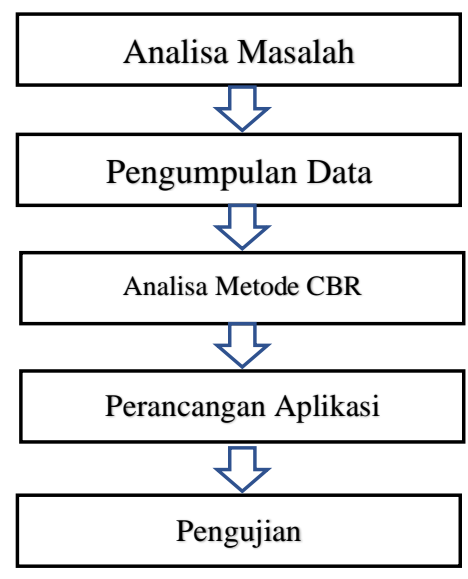

Gambar 1. Tahapan Penelitian

Dari tahapan penelitian diatas dapat dijelaskan bahwa:

1. Analisa Masalah

Melakukan metode penelitian dengan mempelajari mengenai penerapan metode yang digunakan dalam pembuatan sistem diagnose dan aplikasi seperti yang akan dibuat dalam pengindentifikasi masalah.

2. Tahapan Pengumpulan Data.

a. Pengumpulan data dilakukan dengan cara mencari buku-buku pendukung yang berhubungan dengan masalah yang dibahas sebagai acuan untuk memecahkan permasalahan.

b. Penelusuran internet (browsing)

Melakukan browsing di internet untuk memperoleh data-data yang dibutuhkan, sebagai penunjang dalam penelitian yang dilakukan

3. Analisa Metode CBR 
Dalam tahapan ini peneliti melakukan penganalisaan metode dengan menggunakan data-data yang didapatkan dari tempat penelitian, dengan mengikuti tahapan-tahapan yang ada pada Metode CBR

4. Perancangan Aplikasi

Melakukan perancangan aplikasi yang menerapkan metode untuk diagnosa kerusakan televisi.

5. Pengujian

Tahapan pengujian dilakukan langsung terhadap televisi yang akan didiagnosa kerusakannya untuk mengetahui kerusakannya berdasarkan gejala dan nilai bobot yang sudah didapatkan

\subsection{Sistem Pakar}

Sistem pakar adalah sistem yang dapat bekerja atau beroperasi seperti otak manusia. Sistem ini dapat mengambil keputusan layaknya seorang pakar yang mengambil keputusan[7][3]. Sistem ini bekerja dengan langkah-langkah kerja sebagai berikut : akuisisi pengetahuan mengidentifikasi object-atribut-value, menetapkan basis pengetahuan, perancangan basis data, formalisasi sistem pakar,perancangan dan pengembangan perangkat lunak, serta validasi system[8], [9].

\subsection{Metode Case Based Reasoning (CBR)}

Menurut penelitian [10], [11] Case Based Reasoning adalah metode untuk menyelesaikan masalah dengan mengingat kejadian-kejadian yang sama/sejenis (similar) yang pernah terjadi di masa lalu kemudian menggunakan pengetahuan/informasi tersebut untuk menyelesaikan masalah yang baru, atau dengan kata lain menyelesaikan masalah dengan menghadapi solusi-solusi yang pernah digunakan di masa lalu.

$$
\text { Simililarity (problem,case })=\frac{s_{1} * w_{1}+s_{2} * w_{2}+\ldots \ldots+s_{n} * w_{n}}{w_{1}+w_{2}+\ldots \ldots .+w_{n}}
$$

Keterangan:

1. Similarity (nilai kemiripan) yaitu (sama) dan 0 (beda)

2. $\mathrm{W}=$ weight (bobot yang diberikan)

Metode CBR [12]-[15]memiliki empat tahapan proses pengerjaan diantaranya:

1. Retrieve (Memperoleh Kembali)

2. Reuse (Menggunakan)

3. Revise (Meninjau)

4. Retain (Menyimpan)

\section{HASIL DAN PEMBAHASAN}

Cara kerja sistem secara umum berpedoman pada basis pengetahuan yang dimiliki oleh sistem yang bersumber dari kasus-kasus yang pernah ditangani oleh seorang pakar yang kemudian dihitung tingkat kemiripannya dengan kasus baru yang dimasukkan pengguna. Berdasarkan tingkat kemiripan kasus inilah sistem akan mengeluarkan diagnosis kerusakan televisi.

\section{Tahap I : Retrieve \\ Proses pembobotan: \\ Gejala Penting $=5$ \\ Gejala Sedang $=3$ \\ Gejala Biasa $=1$}

Tingkat Kerusakan:

$\begin{array}{ll}0-0,25 & \text { Kecil } \\ 0,27-0,50 & \text { Sedang } \\ 0,52-0,75 & \text { Tinggi } \\ 0,76-1 & \text { Kritis }\end{array}$

Berikut data untuk diagnose pada setiap gejala dan kerusakan televise:

Tabel 1. Bobot Kerusakan Televisi

\begin{tabular}{llcc}
\hline No & \multicolumn{1}{c}{ Gejala Kerusakan } & Kerusakan & Bobot \\
\hline 1 & Tidak ada gambar dan suara & & 1 \\
2 & Mati total dengan lampu indikator & & 1 \\
3 & $\begin{array}{l}\text { Suara derit getaran trafo awitching } \\
\text { lampu indicator menyala tetapi gambar dan }\end{array}$ & Mati Total & 5 \\
4 & $\begin{array}{l}\text { suara tidak muncul } \\
5\end{array}$ & Tidak ada restar tetapi suara baik & 5 \\
6 & Sinkronisasi horizontal jelek & & 1 \\
7 & $\begin{array}{l}\text { Strip hitam tidak dapat hilang dari raster } \\
\text { meskipun sinkronisasi telah di stel }\end{array}$ & 1
\end{tabular}


JURNAL MEDIA INFORMATIKA BUDIDARMA

Volume 5, Nomor 2, April 2021, Page 624-629

ISSN 2614-5278 (media cetak), ISSN 2548-8368 (media online)

Available Online at https://ejurnal.stmik-budidarma.ac.id/index.php/mib

DOI 10.30865/mib.v5i2.2952

\begin{tabular}{llcc}
\hline No & \multicolumn{1}{c}{ Gejala Kerusakan } & Kerusakan & Bobot \\
\hline 8 & Cacat (distorsi) pola raster & & 5 \\
9 & Pemendekan tinggi gambar & & 3 \\
10 & Gambar layar menyempit & & 3 \\
11 & Kontras gambar rendah & & 5 \\
12 & Muncul garis miring pada gambar & Scroll & 5 \\
13 & Gangguan warna & & 3 \\
14 & Adanya bintik putih pada layar & & 1 \\
15 & Tidak ada gambar/suara lemah & & 5 \\
\hline
\end{tabular}

1. Pembobotan gejala kerusakan Pada Televisi

Tabel 2. Perhitungan Kasus Kerusakan Mati Total

\begin{tabular}{|c|c|c|}
\hline Kasus Baru $=\mathbf{X}$ & (S) & Kasus Lama $=$ ID 10 \\
\hline \multicolumn{2}{|l|}{ Gejala: } & Gejala: \\
\hline 1. Tidak ada gambar dan suara & 1 & 1. Tidak ada gambar dan suara \\
\hline 2. Mati total dengan lampu indikator & 1 & 2. Mati total dengan lampu indikator \\
\hline 3. Suara derit Getaran trafo Switching & 3 & Suara derit Getaran trafo Switching \\
\hline $\begin{array}{l}\text { 4. Lampu indikator menyala tetapi gambar dan } \\
\text { suara tidak muncul }\end{array}$ & 5 & $\begin{array}{l}\text { 4. Lampu indikator menyala tetapi gambar } \\
\text { dan suara tidak muncul }\end{array}$ \\
\hline & 5 & 5. Tidak ada restar tetapi suara baik \\
\hline
\end{tabular}

Similarity $(X, 10)=\frac{[(1 * 1)+(1 * 1)+(1 * 3)+(1 * 5)+(0 * 5)]}{1+1+3+5+5}$

$$
\begin{aligned}
& =\frac{1+1+3+5}{15} \\
& =\frac{10}{15} \\
& =0,67
\end{aligned}
$$

\begin{tabular}{|c|c|c|}
\hline Kasus Baru = X & (S) & Kasus Lama =ID 11 \\
\hline Gejala: & & Gejala: \\
\hline 1. Sinkronisasi horizontal jelek & 1 & 1. Sinkronisasi horizontal jelek \\
\hline $\begin{array}{l}\text { 2. Stirp hitam tidak dapat hilang dari restar } \\
\text { meskipun sinkronisasi telah di stel }\end{array}$ & 1 & $\begin{array}{l}\text { 2. Stirp hitam tidak dapat hilang dari } \\
\text { restar meskipun sinkronisasi telah di }\end{array}$ \\
\hline 3. Cacat (distorsi) pola restar & 5 & stel \\
\hline 4. Pemendekan tinggi gambar & 3 & 3. Cacat (distorsi) pola restar \\
\hline
\end{tabular}

2. Pembobotan gejala kerusakan Pada Mesin

Tabel 3. Perhitungan Kasus Kerusakan Mesin

$$
\begin{aligned}
\text { Similarity }(X, 11) & =\frac{[(1 * 1)+(1 * 1)+(1 * 5)+(0 * 3)]}{1+1+5+3} \\
& =\frac{1+1+5+0}{10} \\
& =\frac{7}{10} \\
& =0,70
\end{aligned}
$$

3. Pembobotan gejala Kerusakan Scroll

Tabel 4. Perhitungan Kasus Kerusakan Scroll

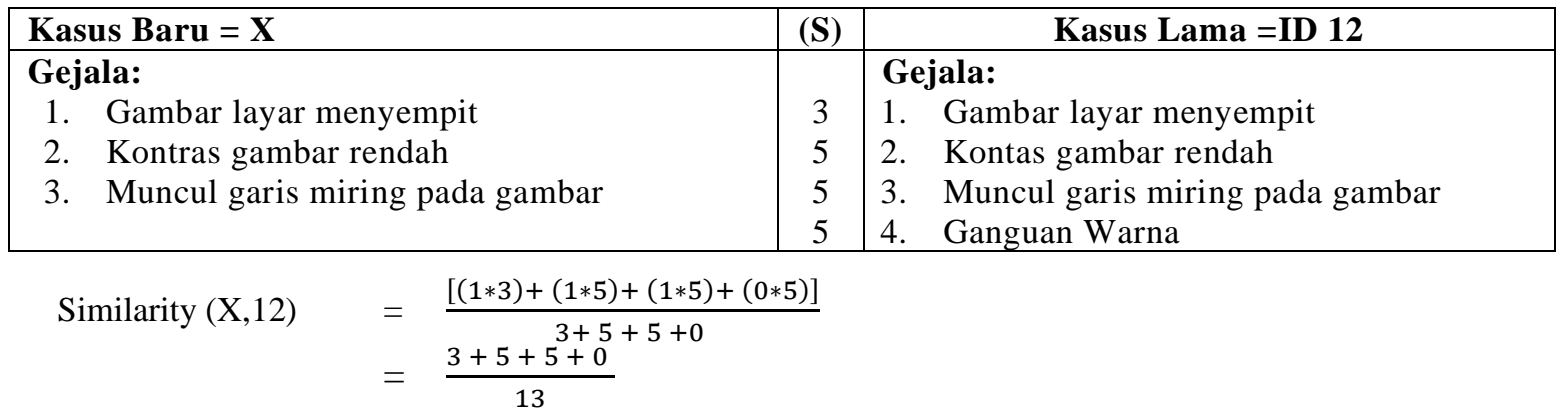




\section{Tahap II: Reuse}

$$
\begin{aligned}
& =\frac{13}{13} \\
& =1
\end{aligned}
$$

Berdasarkan perhitungan diatas kasus yang memiliki bobot kemiripan paling rendah adalah kasus ID 10 yaitu sebesar 0,67. Kasus ID 11 memiliki nilai di urutan kedua sebersar 0,70 dan ID 12 menghasilkan bobot ter tinggi yaitu 1. Pada proses reuse, solusi yang diberikan adalah solusi dengan bobot kemiripan kasus lama dengan kasus baru yang paling tinggi, dalam contoh kasus ini xadalah kasus ID 12 yaitu kerusakan mesin. Hasil perhitungan dengan bobot menunjukkan tingkat kepercayaan lebih dari 90\%, jadi solusi kasus ID 12 lah yang direkomendasikan kepada pengguna Televisi.

\section{Tahap III: Revise}

Proses revise adalah proses peninjauan kembali kasus dan solusi yang diberikan jika pada proses retrieve sistem tidak dapat memberikan hasil diagnosa yang tepat. Pada contoh ini kasus kerusakan televisi sudah menghasilkan solusi dengan tingkat kepercayaan diatas $90 \%$, jadi solusi yang dihasilkan dapat langsung diberikan. Tetapi jika ternyata setelah dilakukan proses perhitungan dan tidak ada kasus yang mirip dengan kasus baru tersebut maka dilakukan proses revise. Informasi berupa masukan gejala pada kasus baru yang tidak ditemukan kemiripannya dengan basis pengetahuan (rule) tersebut akan ditampung pada suatu tabel khusus (tabel revise) yang selanjutnya akan dievaluasi dan diperbaiki kembali oleh pakar untuk menemukan solusi yang tepat.

Berdasarkan dari perhitungan tahapan metode CBR yang dilakukan didapatkan hasil bahwa berdasarkan gejala dari 3 kasus nilai paling tertinggi adalah pada ID 12 dengan nilai keyakinan 1 dan kerusakan Scroll.

\section{KESIMPULAN}

Dari perhitungan diatas kasus yang memiliki bobot paling rendah adalah kasus 3 yaitu rendah adalah kasus ID 10 yaitu sebesar 0,67. Kasus ID 11 memiliki nilai di urutan kedua sebersar 0,70 dan ID 12 menghasilkan bobot ter tinggi yaitu 1. Pada proses reuse solusi yang diberikan adalah solusi dengan bobot kemiripan kasus lama dengan kasus baru yang paling tinggi, dalam contoh kasus ini adalah kasus ID 12 yaitu Konjungtivis Efektif.

\section{UCAPAN TERIMAKASIH}

Penulis mengucapkan terima kasih kepada tim peneliti dan teman-teman dosen di universitas Labuhan Batu yang selalu memberi masukan dan ide-ide dalam penelitian ini, demikian juga terucap buat ketua LPPM Universitas Labuhan Batu atas dukungan kepada peneliti selama menyelesaikan penelitian.

\section{REFERENCES}

[1] M. Arifin, S. Slamin, and W. E. Y. Retnani, "Penerapan Metode Certainty Factor Untuk Sistem Pakar Diagnosis Hama Dan Penyakit Pada Tanaman Tembakau,” Berk. Sainstek, vol. 5, no. 1, p. 21, 2017.

[2] T. E. Putri, D. Andreswari, and R. Efendi, "Implementasi Metode CBR (Case Based Reasoning) dalam Pemilihan Pestisida terhadap Hama Padi Sawah Menggunakan Algoritma K-Nearest Neighbor (KNN) (Studi Kasus Kabupaten Seluma)," J. Rekursif, 2016.

[3] M. Syahrizal and H. Haryati, "Perancangan Aplikasi Sistem Pakar Deteksi Kerusakan Mesin Alat Berat (Beko) Dengan Menerapkan Metode Teorema Bayes," J. MEDIA Inform. BUDIDARMA, 2018.

[4] C. Cubfritua, F. A. Sianturi, and A. Gea, "Sistem Pakar Untuk Mendiagnosa Pertumbuhan Gigi Balita Dengan Menggunakan Metode Dempster Shaper," J. ARMADA Inform., 2018.

[5] Minarni and A. Fadhillah, "Expert System in Detecting Rice Plant Diseases," J. Dyn., vol. 2, no. 1, pp. 11-15, 2017.

[6] B. Sinaga, P. M. Hasugian, and A. M. Manurung, "Sistem Pakar Mendiagnosa Kerusakan Smartphone," vol. 3, no. 1, pp. 333-339, 2018.

[7] S. Murni and F. Riandari, "Penerapan Metode Teorema Bayes Pada Sistem Pakar Untuk Mendiagnosa Penyakit Lambung,” J. Teknol. dan Ilmu Komput. Prima, 2018.

[8] P. Ananta Dama Putra, I. K. Adi Purnawan, and D. Purnami Singgih Putri, "Sistem Pakar Diagnosa Penyakit Mata dengan Fuzzy Logic dan Naïve Bayes," J. Ilm. Merpati (Menara Penelit. Akad. Teknol. Informasi), 2018.

[9] F. A. Sianturi, "Implementasi Metode Certainty Factor Untuk Diagnosa Kerusakan Komputer," MEANS (Media Inf. Anal. dan Sist., vol. 4, no. 2, pp. 176-184, 2019.

[10] T. Syahputra and J. Halim, "Sistem Pakar Untuk Mendiagnosa Penyakit Menular Seksual ( HIV / AIDS ) Dengan Menggunakan Metode Case Based Reasoning ( CBR )," J. Sains dan Komput., 2019.

[11] S. Salamun, "Penerapan Algoritma Nearest Neighbor dan CBR pada Expert System Penyimpangan Perilaku Seksual," J. Online Inform., 2018.

[12] A. Annisa, T. Tursina, and H. S. Pratiwi, "Diagnosis Kerusakan Komputer Menggunakan Metode Similarity Jaccard Coefficient," vol. 5, no. 2, pp. 104-108, 2017.

[13] arno reza Pahlawan and S. Wibisono, "IMPLEMENTASI CASE BASED REASONING UNTUK SISTEM DIAGNOSIS HAMA DAN PENYAKIT TANAMAN CABE MERAH MENGGUNAKAN ALGORITMA SIMILARITAS NEYMAN," SINTAK, 2017. 
JURNAL MEDIA INFORMATIKA BUDIDARMA

Volume 5, Nomor 2, April 2021, Page 624-629

ISSN 2614-5278 (media cetak), ISSN 2548-8368 (media online)

Available Online at https://ejurnal.stmik-budidarma.ac.id/index.php/mib DOI 10.30865/mib.v5i2.2952

[14] M. Syahrizal, R. Irwanti, and M. Sayuthi, "Sistem Pakar Diagnosa Penyakit Zika Dengan Menerapkan Metode Case Base Reasoning,” J. Ris. Komput., vol. 5, no. 3, pp. 240-246, 2018.

[15] R. Avrizal, "Sistem Pakar Mendiagnosa Penyakit Flu Babi Menerapkan Metode Hybrid Case Based," J. Ris. Komput., vol. 6, no. 2, pp. 204-210, 2019. 